\title{
FLT1 Gene Amplification
}

National Cancer Institute

\section{Source}

National Cancer Institute. FLT1 Gene Amplification. NCI Thesaurus. Code C129611.

A molecular genetic abnormality indicating the presence of multiple copies of the FLT1 gene. 